DOI https://doi.org/10.33766/2524-0323.86.235-246

УДК 656.086.1

3. У. Болоташвілі,

кандидат технічних наук, доцент, доцент кафедри тактичної, спеціальної та фізичної підготовки

Луганського державного університету внутрішніх справ імені Е. О. Дідоренка

(м. Севєродонецьк, Україна) e-mail: mail@lduvs.edu.ua

iD https:// orcid.org/0000-0002-0362-6768

\title{
ВОДІЇ ЗІ СТАЖЕМ ДО ДВОХ РОКІВ - ФАКТОР ВИСОКОГО РИЗИКУ ДОРОЖНЬО-ТРАНСПОРТНИХ ПРИГОД В УКРАЇНІ
}

Метою статті є розгляд правових відносин при управлінні механічними транспортними засобами водіями із стажем до двох років (далі водіями новачками) в Україні й пропозиція правових шляхів зниження дорожньотранспортних подій, а також ризику загрози життя, здоров'ю учасників дорожнього руху (водіїв, пішоходів, пасажирів, велосипедистів і мотоциклістів) шляхом коригування розділу "Обов'язку і права водіїв механічних транспортних засобів" справжніх правил дорожнього руху України.

Ключові слова: механічний транспортний засіб, водій, статистика, дорожньо-транспортна подія (ДТП), показник смертності, Департамент патрульної поліції, Сервісний центр МВС України.

Постановка проблеми. Сьогодні наша держава входить до складу світових лідерів за кількістю смертельних випадків у результаті дорожньотранспортних пригод разом із Грузією, Вірменією, Індією, Росією та США. Показники смертності за результатами дорожньо-транспортних пригод в Україні вищі (більше ніж у 3 рази, ніж у країнах Євросоюзу). Причинами, які призводять до смертності на дорогах, є наступні: незакріплення ременями безпеки; керування транспортними засобами в стані алкогольного, наркотичного чи іншого сп'яніння або під впливом лікарських препаратів; перевищення швидкості; ігнорування мотоциклетних шоломів; перевезення дітей, які не досягли 12 років або зросту 145 см без спеціального сертифікованого дитячого крісла; неправильний проїзд перехресть, залізничних переїздів, естакад, шляхопроводів, мостів; рух по смузі для маршрутних транспортних засобів, позначеній дорожніми знаками 5.8 або 5.11; ігнорування сигналів світлофора, регулювальника, дорожніх знаків, дорожньої розмітки. Левова частка всіх цих порушень правил дорожнього руху приходиться на водіїв-новачків зі стажем до двох років. У правилах дорожнього руху України немає конкретного регулювання щодо експлуатації механічних транспортних засобів водіями - новачками зі стажем до двох років, 
крім як заборона перевищувати швидкість у 70 кілометрів на годину. Вище сказане говорить про те, що необхідний підпункт «Вимоги до водіїв зі стажем до двох років» із конкретними обмеженнями під час руху по дорогах України. Також потребує серйозного доопрацювання кодекс України про адміністративні правопорушення та Кримінальний кодекс України в змісті про протиправні порушення водіїв зі стажем до двох років.

Аналіз останніх досліджень і публікацій. Проблема удосконалення національного законодавства з питань безпеки дорожнього руху цікавить багатьох науковців, серед яких є такі, як: В. Новіков, М. Попов, Л. Кононенко, О. Міленін, А. Васильєв, Ф. Гончаренко, Л. Коваль, Н. Нижник та інші. Саме дослідження О. Білошицького,В. Еннанова, С. Новака, С. Товстухи, С. Стаскевича лягли в основу вивчення питання щодо участі молодих водіїв у ДТП.

Формування цілей. Метою статті є розгляд правових відносин при управлінні механічними транспортними засобами водіями зі стажем до двох років (далі водіями-новачками) в Україні й можливих правових шляхів зниження дорожньо-транспортних пригод, а також ризику загрози життю, здоров'ю учасників дорожнього руху (водіїв, пішоходів, пасажирів, велосипедистів та мотоциклістів) шляхом коригування розділу «Обов'язки й права водіїв механічних транспортних засобів» щодо справжніх правил дорожнього руху України.

Виклад основного матеріалу. Автомобільний транспорт посідає одне з перших місць в економічному розвитку нашої держави. На його частку припадає близько 62 \% річного обсягу перевезень вантажів і пасажирів. Автомобільний транспорт є сполучною ланкою в загальній системі залізничних, авіаційних і морських перевезень. Основною проблемою сучасного етапу розвитку автомобільного транспорту є зниження ризику загрози життю, здоров'ю учасників дорожнього руху в результаті настання дорожньо-транспортної пригоди.

Згідно 3 офіційною статистикою в Україні в п'ять разів більше смертельних ДТП, ніж у країнах Євросоюзу. Практично щороку в нашій державі за результатами ДТП гине понад 3 тисячі осіб і понад 30 тисяч отримують травми різного ступеня тяжкості. Щорічно через ДТП Україна втрачає 5 мільярдів доларів, що становить 2,5\% валового внутрішнього продукту [8]. За даними керівника «Укравтодору» Славоміра Новака встановлено, що ДТП завдають нашій державі збитків у розмірі 1,5-2,5 \% валового внутрішнього продукту. ДТП завдають економіці України комплексного збитку. За даними дослідження Світового банку, а саме автором Патріціо Маркесом, встановлено, що дорожньо-транспортний травматизм є основною причиною смертності та інвалідності серед усіх видів травматизму. У свою чергу дорожньо-транспортний травматизм вражає людей молодого та працездатного віку. Психофізіологічне відновлення постраждалих учасників дорожньо-транспортних пригод викликає велике навантаження на службу охорони здоров'я та соціального захисту держави [8]. За офіційною статистикою за 15 років в Україні в ДТП загинуло 74 тисячі чоловік. Приблизно 
75\% травмованих від ДТП в Україні набувають летального результату до повної госпіталізації, тоді як у Євросоюзі тільки 28 \%. За даними Міністерства охорони здоров'я України ДТП в нашій державі є першою за поширеністю смертей молоді у віці від 15 до 24 років. За останні шість років на дорожніх артеріях України загинуло 1,4 тисячі дітей. Понад 43 \% загиблих у результаті ДТП за 2016 рік - це пішоходи і велосипедисти. У результаті ДТП щорічно отримують травми десятки тисяч людей. За 15 років ведення офіційної статистики в Україні було травмовано 603 тисячі осіб [8-9].

Безсумнівно, величезну роль на безпеку дорожнього руху нашої держави впливає вік автомобільного парку. Автопарк Украӥни - один з найстаріших у світі. Середній вік легкового транспорту в Україні становить близько 16 років. Наша держава лише значно поступається ряду держав: Саудівській Аравії (3,5 роки), Люксембург (5,5 років), Німеччина (7 років), тоді як Україна перебуває «в близькості» до таких країн, як Словаччина (11,3 роки), США (11,5 років) [10].

Для повноти картини наведемо дані про кількість транспортних засобів, наявних в Україні, а саме: легкових авто - 6,566 мільйонів, автобусів - 250 тисяч, мотоциклетного транспорту - близько 840 тисяч [10]. Автомобільний парк України досить значний і вимагає постійного контролю технічного стану з боку Патрульній поліції, Сервісного центру МВС України та інших контролюючих організацій, оскільки від цього залежить безпека дорожнього руху.

Аналізуючи статистику ДТП Національної адміністрації дорожньої безпеки США (NHTSA), видно, що рік випуску автомобіля безпосередньо пов'язаний із високим ризиком загинути при ДТП в ньому. Експерти NHTSA розглянули дані про ДТП за період з 2005 по 2011 роки і назвали конкретні шанси летального результату в залежності від року випуску автомобіля. За даними NHTSA, водії автомобілів старше 18 років гинуть в аваріях частіше за всіх - шанс летального результату в їх випадку виявляється на 71 \% вищим, ніж якби вони мали автомобіль не старіше ніж 3 роки. Якщо автомобіль від чотирьох до семи років, то шанс загинути в аварії в порівнянні з власником того ж трирічного автомобіля зростає на 30 \%. Решта розглянуті в NHTSA вікові діапазони автомобіля також протиставлені трирічним автомобілям автомобілі віком від 8 до 11 років на 19 \% більш небезпечні, від 12 до 14 років небезпечніше на $32 \%$, від 15 до 17 років - на 50 \% [11].

Слід також зазначити, що вже підготовлений законопроект про повернення технічного огляду автомобільного транспорту. Законопроект встановлює єдину дату початку проведення техоглядів. Планується, що 31 січня 2022 року всі приватні легкові автомобілі, мотоцикли й мопеди проходитимуть перевірку на експлуатаційну придатність. Процедура проходження технічного огляду буде проводиться кожні 2 роки [12]. Законопроект конкретно передбачає, що' саме необхідно буде перевірити експерту при проходженні регулярного технічного огляду автомобіля.

Згідно із законопроектом, список деталей і вузлів автомобіля необхідний для перевірки експертом узяти відповідно (наприклад) не 3 дизайнерських можливостей, а саме з умов впливу технічного стану на безпеку дорожнього руху (наприклад, маневреність чи гальмівний шлях), а саме: 1) системи 
рульового і гальмівного управління; 2) справності зовнішніх приладів освітлення, сигнальної і аварійної системи, склоочисників; 3) скатів і дисків коліс; 4) рівня тонування машини (лобове скло, передні бічні, передні стекла на дверях); 5) стану газобалонного обладнання; 6) ідентифікації складових частин, систем, у тому числі встановленого обладнання; 7) рівня токсичності вихлопних газів $\left.\left(\mathrm{CO}, \mathrm{CO}_{2}, \mathrm{HC}, \mathrm{O}_{2}\right) ; 8\right)$ наявності вогнегасника, аптечки першої допомоги та знаків аварійної зупинки.

За результатами позитивної перевірки власнику транспортного засобу експерт зобов'язаний буде видати спеціальний талон, який у майбутньому можуть оснастити електронним чіпом. Талон технічного огляду повинен містити інформацію про дату проведення огляду, а також інформацію про придатність його до експлуатації [12]. До того ж, можна вважати великим успіхом у сфері безпеки дорожнього руху України, що з 1 травня 2019 року власники транспортних засобів, що підлягають обов'язковому техогляду, разом із паперовим бланком про проходження технічного контролю отримуватимуть самоклеючу мітку радіочастотної ідентифікації, яку потрібно прикріпити до лобового скла [13]. Це дозволить поліцейським зчитувати мітки на відстані за допомогою спеціальних пристроїв. Таким чином, вони зможуть перевіряти, чи має дозвіл транспортний засіб до участі в дорожньому русі.

Отже, основними факторами високої смертності в дорожньотранспортних пригодах по Україні є низька якість автомобільних доріг, а також психологічна неготовність молодих водіїв (особливо зі стажем до двох років) до участі в дорожньо-транспортному русі. [14].

Далі розглянемо статистичні дані Департаменту патрульної поліції МВС України за кількістю ДТП з даними про кількість постраждалих, травмованих і загиблих за період з 2006 року по 2018 рік (див. мал.1) [2-3].

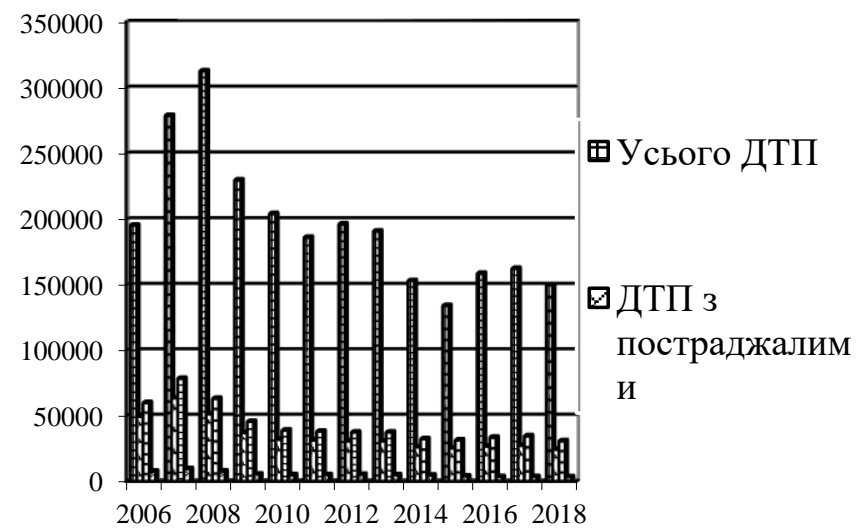

Мал.1. Статистика про кількість ДТП в Україні 3 постраждалими, травмованими і загиблими в період з 2006 року до 2018 року (статистичні дані Департаменту патрульної поліції МВС України) [2-3]. 
За даними заступника начальника Департаменту патрульної поліції Олексія Білошицького (дивись рис.1 2017 і 2018 роки) встановлено, що в порівнянні з 2017 роком у 2018 році на дорогах України зафіксовано зниження за основними чотирма показниками статистики ДТП:

- кількість ДТП зменшилася на 12406 випадків;

- кількість ДТП з потерпілими зменшилася на 2926 випадків;

- кількість травмованих зменшилася на 3793 випадків;

- кількість загиблих в ДТП скоротилося на 82 людини.

Аналізуючи вище наведені дані Департаменту патрульної поліції (дивись мал.1), найбільша кількість ДТП на автомобільних дорогах України зареєстрована в 2008 році - 312751 випадки, тоді як в 2018 році - 150120 випадків, математично в 2 рази менше. Найбільша кількість ДТП 3 постраждалими було зафіксовано в 2007 році - 63554 випадки. Проте 2018 рік приніс значне зниження кількості ДТП - до 24294 випадків, а це в 2,5 рази менше. Також заступник начальника Департаменту патрульної поліції Білошицький зазначив наступне, що показники покращилися при прийнятті конкретних заходів Національною поліцією України в минулому 2018 році. Точніше, це збільшення території патрулювання й кількості екіпажів. За даними О. Білошицького в даний час траси міжнародного і національного значення України щозміни контролюють 200 екіпажів патрульної поліції, i загальна протяжність ділянок знаходяться під контролем становить 6500 км. Заступник начальника Департаменту патрульної поліції Олексій Білошицький вказав на наступне, що в 2018 році була проведена наступна упереджувальна робота поліцейськими:

- при використанні лазерних радарів TruCam для фіксації швидкісного режиму за 2,5 календарних місяці поліцейські зафіксували понад 25 тисяч правопорушень;

- видано понад 11 тисяч вимог (приписів) на усунення недоліків;

- оформлені 2815 адміністративних протоколів та 8037 постанов у сфері безпеки дорожнього руху, зокрема стану утримання доріг;

- винесено понад 1,4 мільйони постанов і більше 168 тисяч протоколів про порушення правил дорожнього руху.

Також слід зазначити, що великому ризику потрапити в ДТП піддаються молоді водії віком до 25 років [4-5]. Перший рік управління механічним транспортним засобом після отримання водійських прав $є$ небезпечним періодом, а саме: відсутність досвіду в поєднанні з надмірною самовпевненістю часто призводять до ДТП. За статистикою близько $40 \%$ молодих водіїв віком до 25 років мінімум як 1 раз є учасниками ДТП [4-5].

Порівняємо ж аналогічну ситуацію 3 Ізраїлем. У ході проведення круглого столу, організованого Україно-Ізраїльським інститутом стратегічних досліджень імені Голди Меїр, у прес-центрі «Українські новини» директор інституту Альберт Фельдман зазначив, що в Ізраїлі проблема високої смертності в ДТП також гостра, як і в Україні [14]. На думку Альберта Фельдмана, одна з причин - лояльність ізраїльської та української каральної системи до водіїв. Щодо України, то однією з основних причин 
високої смертності в ДТП експерт вважає поганий стан дорожньої інфраструктури і наявність водіїв зі стажем до двох років [14]. У свою чергу, глава правління Всеукраїнського партнерства за безпеки дорожнього руху Михайло Берлін сказав, що Україна щорічно має 40 мільярдів гривень збитку від ДТП, і з цієї суми 70 \% - збиток від загибелі людей. Молоді водії істотно впливають на кількість втрат від ДТП [14]. При цьому в Патрульної поліції слабо враховується фактор «молоді водії» при аналізі причин аварій і не ведеться відповідна статистика. Учені та експерти встановили, що найбільшу економічну шкоду Україні несе за фактом загибелі чоловіків віком до 28 років. Експерти впевнені, що даний фактор є основною причиною суттєвого зниження населення України. За даними Берліна зрозуміло, що високий відсоток ДТП за участю молодих водіїв обумовлений відсутністю у них необхідного досвіду і поганою підготовкою в автошколах [14].

Високий відсоток молодих водіїв у ДТП зі смертельним результатом за останнє десятиліття стало проблемою номер один у забезпеченні безпеки дорожнього руху не тільки України, а й усієї світової спільноти. За даними громадської організації економічного співробітництва у розвитку були встановлені наступні статистичні факти, які напевно дозволять задуматися молодим водіям про достатність їх навичок водіння відповідно до зростаючої аварійністю на автошляхах. На участь молоді в ДТП припадає близько $27 \%$ всіх загиблих водіїв, хоча ця вікова група становить лише близько $10 \%$ населення. Також 20-30 \% всіх смертельних випадків в ДТП - результат пригод за участю молодого водія [15]. За статистикою щодня в дорожньотранспортних аваріях гине більше 1000 дітей і молодих людей віком до 25 років. Дорожньо-транспортні травми є основною причиною смерті людей віком 10-24 років. Також статистикою встановлено, що частка молодих водіївчоловіків у смертельних випадках при ДТП втричі більше, ніж серед молодих жінок, і залишається набагато вищою навіть із поправкою на коефіцієнт їх більшою схильністю до ризику [15].

Безсумнівно, висока роль у забезпеченні безпеки дорожнього руху відводиться нормативно-правовій базі України, яка відображена в наступних основних документах: Правила дорожнього руху України [16]; Закон України «Про дорожній рух» [17]; Постанова КМУ від 25 квітня в 2018 р. N 435 «Про затвердження Державної програми підвищення рівня безпеки дорожнього руху в Україні на період до 2020 року» [18].

Тільки розділ 12 «Швидкість руху» п. 12.6. (б) справжніх правил дорожнього руху України дає обмеження швидкості руху не більше 70 км за годину для водіїв зі стажем до 2 років. Це є єдиним обмеженням для водіївновачків зі справжніх правил дорожнього руху України.

Проведені правові дослідження в сфері дорожнього руху для водіїв новачків дають підставу визначити наступне, що в справжніх правил дорожнього руху України необхідний додатковий підпункт у розділ «Обов'язки і права водіїв механічних транспортних засобів», а саме: «Водієві зі стажем до двох років забороняється», при цьому доповнивши цей підпункт наступними обмеженнями: 
а) перевозити вантаж, який виступає за габарити транспортного засобу спереду і ззаду;

б) перевозити дітей віком до 12 років без супроводу особи, яка досягла 18- річного віку;

в) брати участь у будь-якому вигляді буксирування транспортних засобів, а також знаходитися в транспортному засобі, яке підлягає буксируванню відповідно;

г) рухатися по автомобільній дорозі, позначеній дорожнім знаком 5.1 «Автомагістраль»;

г) рухатися по гірських дорогах і на крутих підйомах та спусках під час ожеледиці.

Безсумнівно, при введенні таких обмежень у справжні правила дорожнього руху України для водіїв зі стажем до двох років дозволить значно скоротити кількість дорожньо-транспортних пригод. У свою чергу це призведе до скорочення кількості загиблих і покалічених людей. Відповідно, знизиться навантаження на службу охорони здоров'я та соціального захисту України і в цілому призупиниться скорочення населення, а це має не менш важливе значення для підвищення внутрішнього валового продукту.

Висновки. У зв'язку з високою щільністю транспортного потоку по дорогах України почастішали випадки виникнення ДТП, особливо за участю водіїв зі стажем до двох років. Високий відсоток молодих водіїв у ДТП зі смертельним результатом за останнє десятиліття стало проблемою номер один у забезпеченні безпеки дорожнього руху України. Величезної економічної шкоди Україні завдає фактом загибелі людей віком до 28 років. Цей фактор є основною причиною суттєвого зниження чисельності населення України.

На основі вищевикладеного матеріалу в галузі правових відносин дорожнього руху України склалася гостра необхідність у коригуванні цих правил дорожнього руху України (щодо молодих водіїв зі стажем не більше 2 років).

У справжніх правилах дорожнього руху України (розділ «Обов'язки і права водіїв механічних транспортних засобів») необхідний додатковий підпункт «Водієві зі стажем до двох років забороняється» 3 наступними обмеженнями:

а) перевозити вантаж, який виступає за габарити транспортного засобу спереду і ззаду;

б) перевозити дітей віком до 12 років без супроводу особи, яка досягла 18 річного віку;

в) брати участь у будь-якому вигляді буксирування транспортних засобів, а також знаходиться в транспортному засобі, яке підлягає буксируванню відповідно;

г) рухатися по автомобільній дорозі, позначеній дорожнім знаком 5.1 «Автомагістраль»;

г) рухатися по гірських дорогах і на крутих підйомах та спусках під час ожеледиці. 
Введення підпункту «Водієві зі стажем до двох років забороняється» в справжні правила дорожнього руху дозволить скоротити кількість дорожньо-транспортних пригод і смертність на дорогах України.

\section{Використані джерела:}

1. Смерть на дорозі: Причини і світові лідери за смертністю внаслідок ДТП. 112.UA: Київ, 2017. [Електронний ресурс]. - Режим доступу: https:/ /112.ua/.../ smertna-doroge-prichiny-i-mirovye-lidery-po-smertnosti-v-rezultate.

2. Опублікована статистика ДТП в Україні в 2018 році. Autoua.net: Київ, 2019. [Електронний ресурс]. - Режим доступу: http: // autonews.autoua.net/.../20627opublikovana-statistika-dtp-v-ukraine-v-2018-gody.ht.

3. Статистика ДТП в Україні за період з 01.01.2018 по 31.12.2018:DTP 12-2018. Департамент патрульної поліції України: Київ, 2019. [Електронний ресурс]. - Режим доступу: http: // patrol.police.gov.ua/ru/statystyka/.

4. Автомобілісти якого віку частіше потрапляють в ДТП. Автоцентр / Автоправо / ПДР та безпека: Київ, 2018. [Електронний ресурс]. - Режим доступу: https://www.autocentre.ua/avtopravo/pdd-i-bezopasnost/avtomobilisty-kakogovozrasta-chashhe-popadayut-v-dtp-451479.html.

5. Чому водії-початківці частіше потрапляють у ДТП. Автоцентр / Новини / Подія: Київ, 2018. [Електронний ресурс]. - Режим доступу: https: // www.autocentre.ua/ua/news/sobytie/pochemu-nachinayuschie-voditeli-chaschepopadayut-v-dtp-294222.html.

6. Соцопитування показало, що 93\% початкуючих водіїв, вважають себе профі. Автовод / Новини. 2016. [Електронний ресурс]. - Режим доступу: https:/ /avtovod.com.ua/news/738484289-socopros-pokazal-chto-93-nachinayuschihvoditeley-schitayut-sebya-profi.html.

7. Яцківський Л.Ю., Зеркалов Д.В. Загальний курс транспорту: Навчальний посібник. - Кн. 1. - К.: Арістей, 2007. - 544 с. [Електронний ресурс]. - Режим доступу: http://zerkalov.org.ua/node/23

8. Смерть на дорогах України. Copyright (c) 2018. Україна кримінальна. [Електронний ресурс]. - Режим доступу: https: //cripo.com.ua/scandals.

9. Щороку в аваріях гине близько 1,35 мільйонів людей, - ВООЗ. 112.UA: Київ, 2019. [Електронний ресурс]. - Режим доступу: https://ua.112.ua/avarii$\mathrm{np} /$ shchoroku-v-avariiakh-hyne-blyzko-135-mln-liudei-vooz-483120.html.

10. Названа точна кількість автомобілів в Україні та їх середній вік. Авто 24ТВ: 2018. [Електронний ресурс]. - Режим доступу: https://auto.24tv.ua/nazvana_tochna_kilkist_avtomobiliv_v_ukraini_ta_yikh_serednii_ vik_n6262.

11. Наскільки великий ризик загинути в ДТП залежно від віку машини. Delo.UA: 2013. [Електронний ресурс]. - Режим доступу: https:/ / delo.ua/business/naskolko-velik-risk-pogibnut-v-dtp-v-zavisimosti-otvozrasta-m-216260.

12. В Україну повертають техогляд - названа нова дата. (C) 2006-2019 Prosto Media Group: 2018. [Електронний ресурс]. - Режим доступу: https://prostopravo.com.ua/avto/stati/v_ukrainu_vozvraschayut_tehosmotr_nazvana _novaya_data.

13. Із 1 травня в Україні змінюється порядок проходження техогляду. Інтернет-видання «ГОРДОН»: 2019. [Електронний ресурс]. - Режим доступу: 
https://gordonua.com/ukr/news/society/z-1-travnja-v-ukrajini-zminjujetsja-porjadokprohodzhennja-tehogljadu-731359.html.

14. Молоді водії і погані дороги є основними чинниками високої смертності в ДТП в Україні, - експерти. Українські новини: 2018. [Електронний ресурс]. - Режим доступу: https://ukranews.com/news/584933-molodye-vodytely-y-plokhye-dorogyyavlyayutsya-osnovnymy-faktoramy-vysokoy-smertnosty-v-dtp-v.

15. Молодий початкуючий водій - найнебезпечніший водій. Центр навчання водінню ІНТЕНСИВ (shturman.kiev.ua): 2018. [Електронний peсурс]. - Режим доступу: https://intensive-driving.kiev.ua/molodoynachinauschiy-vodite.htm\#pll_switcher.

16. Постанова Кабінету Міністрів України від 10 жовтня 2011 р. № 1306 «Про затвердження Правил дорожнього руху» (ЗП України, від 01.05.2019, № 46-2019-п). [Електронний ресурс]. - Режим доступу: https:/ / zakon0.rada.gov.ua/laws/show/1306-2001-п.

17. Закон України «Про дорожній рух» (Відомості Верховної Ради України (ВВР), 1993, № 31, ст.338). [Електронний ресурс]. - Режим доступу: https:/ / zakon.rada.gov.ua/laws/show/3353-12?lang=uk.

18. Постанова Кабінету Міністрів України від 25 квітня 2018 р. N 435 «Про затвердження Державної програми підвищення рівня безпеки дорожнього руху в Україні на період до 2020 року». [Електронний ресурс]. - Режим доступу: http://search.ligazakon.ua/1_doc2.nsf/link1/KP180435.html.

\section{References}

1. Smert` na dorozi: Pry`chy`ny`i svitovi lidery`za smertnistyu vnaslidok DTP. 112. UA: Ky`yiv, 2017. [Elektronny`jresurs]. - Rezhy`mdostupu: https:/ /112.ua/.../ smert-na-doroge-prichiny-i-mirovye-lidery-po-smertnosti-vezultate. [in Ukrainian]

2. Opublikovana staty`sty`ka DTP v Ukrayini v 2018 roci. Autoua.net: Ky`yiv, 2019. [Elektronny`j resurs]. - Rezhy`m dostupu: http: // autonews.autoua.net/.../20627opublikovana-statistika-dtp-v-ukraine-v-2018-gody.ht. [in Ukrainian]

3. Staty`sty`ka DTP v Ukrayini za period z 01.01.2018 po 31.12.2018:DTP 12-2018. Departament patrul`noyi policiyi Ukrayiny`: Ky`yiv, 2019. [Elektronny`j resurs]. Rezhy`m dostupu: http: // patrol.police.gov.ua/ru/statystyka/. [in Ukrainian]

4. Avtomobilisty yakogo viku chastishe potraplyayut v DTP. Avtocentr / Avtopravo / PDR ta bezpeka: Ky`yiv, 2018. [Elektronny`j resurs]. - Rezhy`m dostupu: https://www.autocentre.ua/avtopravo/pdd-i-bezopasnost/avtomobilisty-kakogovozrasta-chashhe-popadayut-v-dtp-451479.html. [in Ukrainian]

5. Chomu vodiyi-pochatkivci chastishe potraplyayut`u DTP. Avtocentr / Novy`ny` / Podiya: Ky`yiv, 2018. [Elektronny`j resurs]. - Rezhy`m dostupu: https: // www.autocentre.ua/ua/news/sobytie/pochemu-nachinayuschie-voditeli-chaschepopadayut-v-dtp-294222.html. [in Ukrainian]

6. Soczopy`tuvannya pokazalo, shho $93 \%$ pochatkuyuchy`x vodiyiv, vvazhayut sebe profi. Avtovod / Novy`ny`. 2016. [Elektronny`j resurs]. - Rezhy`m dostupu: https://avtovod.com.ua/news/738484289-socopros-pokazal-chto-93 nachinayuschihvoditeley-schitayut-sebya-profi.html.Yzkivskiy L.Y., Zerkalov D.V. Flat rate of transport : train aid. - Kн. 1. - Kyiv: Aristey, 2007. are 544 p.s [Electronic resource]. it is access Mode: http:/ / zerkalov.org.ua/node/23. [in Ukrainian] 
7. Yaczkivs`ky`j L.Yu., Zerkalov D.V. Zagal`ny`j kurs transportu: Navchal`ny`j posibny`k. - Kn. 1. - K.: Aristej, 2007. - 544 s. [Elektronny`j resurs]. - Rezhy`m dostupu: http:/ / zerkalov.org.ua/node/23. [in Ukrainian]

8. Smert na dorogax Ukrayiny`. Copyright (c) 2018. Ukrayina kry`minal`na. [Elektronny`j resurs]. - Rezhy`m dostupu: https: //cripo.com.ua/scandals. [in Ukrainian]

9. Shhoroku v avariyax gy`ne bly`z’ko 1,35 mil`joniv lyudej, - VOOZ. 112.UA: Ky`yiv, 2019. [Elektronny`j resurs]. - Rezhy`m dostupu: https://ua.112.ua/avarii$\mathrm{np} /$ shchoroku-v-avariiakh-hyne-blyzko-135-mln-liudei-vooz-483120.html. [in Ukrainian]

10. Nazvana tochna kil 'kist` avtomobiliv v Ukrayini ta yix serednij vik. Avto 24TV: 2018. [Elektronny`jresurs].Rezhy`mdostupu:https://auto.24tv.ua/nazvana_t ochna_kilkist_avtomobiliv_v_ukraini_ta_yikh_serednii_vik_n6262. [in Ukrainian]

11. Naskil`ky`vely`ky`j ry`zy`k zagy`nuty`v DTP zalezhno vid viku mashy`ny`. Delo.UA:2013.[Elektronny`jresurs].Rezhy`mdostupu: https://delo.ua/business/nask olko-velik-risk-pogibnut-v-dtp-v zavisimosti-ot vozrasta-m-216260. [in Ukrainian]

12. V Ukrayinu povertayut texoglyad - nazvana nova data. (C) 2006-2019 Prosto Media Group: 2018. [Elektronny j resurs].Rezhy`mdostupu:https:/ / prostopravo.c om.ua/avto/stati/v_ukrainu_vozvraschayut_tehosmotr_nazvana_novaya_data. Young drivers and bad roads are the basic factors of high death rate in travelling transport events in Ukraine, are experts. Ukrainian news: 2018. [Electronic resource]. it is access Mode: https:/ / ukranews.com/news/584933-molodye-vodytely-y-plokhye-dorogyyavlyayutsya-osnovnymy-faktoramy-vysokoy-smertnosty-v-dtp-v. [in Ukrainian]

13. Iz 1 travnya v Ukrayini zminyuyet sya poryadok proxodzhennya texoglyadu. Internet-vy`dannya «GORDON»: 2019. [Elektronny`j resurs]. - Rezhy`m dostupu: https://gordonua.com/ukr/news/society/z-1-travnja-v-ukrajini-zminjujetsja-porjadokprohodzhennja-tehogljadu-731359.html. [in Ukrainian]

14. Molodi vodiyi i pogani dorogy`ye osnovny`my`chy`nny`kamy`vy`sokoyi smertnosti v DTP v Ukrayini, - eksperty`. Ukrayins`ki novy`ny`: 2018. [Elektronny`j resurs]. - Rezhy`m dostupu: https://ukranews.com/news/584933molodye-vodytely-y-plokhye-dorogy-yavlyayutsya-osnovnymy-faktoramyvysokoy-smertnosty-v-dtp-v. [in Ukrainian]

15. Molody`j pochatkuyuchy` $j$ vodij - najnebezpechnishy $j$ vodij. Centr navchannya vodinnyu INTENSY'V (shturman.kiev.ua): 2018. [Elektronny`j resurs]. Rezhy`m dostupu: https://intensive-driving.kiev.ua/molodoy-nachinauschiyvodite.htm\#pll_switcher. [in Ukrainian]

16. Postanova Kabinetu Ministriv Ukrayiny` vid 10 zhovtnya 2011 r. \# 1306 «Pro zatverdzhennya Pravy`l dorozhn`ogo ruxu» (ZP Ukrayiny`, vid 01.05.2019, \# 46-2019-p). [Elektronny`jresurs].- Rezhy`m dostupu: https:/ / zakon0.rada.gov.ua/laws/show/13062001-p. [in Ukrainian]

17. Zakon Ukrayiny «Pro dorozhnij rux» (Vidomosti Verxovnoyi Rady` Ukrayiny` (VVR), 1993, \# 31, st.338). [Elektronny`j resurs]. - Rezhy`m dostupu: https:/ / zakon.rada.gov.ua/laws/show/3353-12?lang=uk. [in Ukrainian]

18. Postanova Kabinetu Ministriv Ukrayiny` vid 25 kvitnya 2018 r. N 435 «Pro zatverdzhennya Derzhavnoyi programy` pidvy`shhennya rivnya bezpeky` dorozhn`ogo ruxu v Ukrayini na period do 2020 roku». [Elektronny`j resurs]. - Rezhy`m dostupu: http://search.ligazakon.ua/1_doc2.nsf/link1/KP180435.html. [in Ukrainian] 
Болоташвили 3.У., кандидат технических наук, доцент, доцент кафедры тактической, специальной и физической подготовки Луганского государственного университета внутренних дел имени Э. А. Дидоренко

(г. Северодонецк, Украина)

\title{
ВОДИТЕЛИ СО СТАЖЕМ ДО ДВУХ ЛЕТ - ФАКТОР ВЫСОКОГО РИСКА ДОРОЖНО-ТРАНСПОРТНЫХ ПРОИСШЕСТВИЙ В УКРАИНЕ
}

\begin{abstract}
Целью статьи является рассмотрение правовых отношений при управлении механическими транспортными средствами водителями со стажем до двух лет (далее водителями-новичками) в Украине и предложение правовых путей снижения дорожно-транспортных происшествий, а также риска угрозы жизни, здоровью участников дорожного движения (водителей, пешеходов, пассажиров, велосипедистов и мотоциклистов) путем корректировки раздела «Обязанности и права водителей механических транспортных средств» настоящих правил дорожного движения Украины.
\end{abstract}

Ключевые слова: механическое транспортное средство, водитель, статистика, дорожно-транспортное происшествие (ДТП), показатель смертности, Департамент патрульной полиции, Сервисный центр МВД Украины.

Bolotashvili Z.,

candidate of technical sciences,

Associate Professor, associate professor of the department of tactical, special and physical training of Lugansk State university of internal affairs named after E. A. Didorenko (Sievierodonetsk, Ukraine)

\section{DRIVERS WITH EXPERIENCE OF UP TO TWO YEARS ARE A FACTOR OF HIGH RISK OF ROAD ACCIDENTS IN UKRAINE}

Due to the high density of traffic on the roads of Ukraine, the occurrence of accidents, especially involving drivers with experience of up to two years, has become frequent. A high percentage of young drivers in fatal accidents over the past decade has become the number one problem in ensuring road safety in Ukraine. A huge economic damage to Ukraine is due to the death of men under the age of 28 years. This factor is the main cause of a significant decline in the population of Ukraine. On the basis of the above material in the field of the legal relations of the road of Ukraine, there is an urgent need to adjust these road rules of Ukraine, namely for young drivers with experience of not more than 2 years.

The purpose of the article is to consider the legal relations in the management of motor vehicles by drivers with experience of up to two years (hereinafter referred to as novice drivers) in Ukraine and to propose legal ways to reduce traffic accidents and the risk of danger to life and health of road users (drivers, pedestrians, passengers, cyclistand motorcyclists) by adjusting the section "Obligations and rights of drivers of motor vehicles" of these traffic rules of Ukraine. 
Key words: motor vehicle, driver, statistics, road traffic accident (RTA), mortality rate, Department of Patrol Police, Service Center of the Ministry of Internal Affairs of Ukraine.

\section{DOI}

УДК 343.98

М. А. Готвянська, аспірантка Донецького юридичного інституту МВС України (м. Кривий Ріг, Україна) e-mail: postmaster@dli.donetsk.ua iD https://orcid.org/0000-0002-0246-4621

\section{ТАКТИКА ДОПИТУ НЕПОВНОЛІТНЬОГО, ВТЯГНУТОГО У ЗЛОЧИННУ ДІЯЛЬНІСТЬ (ОКРЕМІ АСПЕКТИ)}

У статті розглянуто окремі аспекти тактики допиту неповнолітнього, втягнутого в злочинну діяльність. Акцентовано увагу на процесуальних особливостях допиту неповнолітньої особи, висвітлено проблеми, 3 якими стикаються на практиці, а також надано пропозиції щодо їх усунення. Зазначено на важливості підготовчого етапу до допиту, висвітлено тактичні особливості встановлення психологічного контакту 3 неповнолітнім, рекомендовано максимальне використання можливостей вільної розповіді. Звернено увагу на роль криміналістичних знань під час допиту.

Ключові слова: кримінальне провадження, тактика допиту неповнолітнього, дорослий, криміналістичні рекомендації, втягнення в злочинну діяльність.

Постановка проблеми. Однією 3 розповсюджених слідчих (розшукових) дій при розслідуванні будь-яких правопорушень є допит. Метою його проведення є отримання повних та правдивих показань про події та факти, що мають значення для встановлення істини в кримінальному провадженні. Саме допит у багатьох випадках є основним джерелом отримання інформації про подію, що сталась, і показання свідків або потерпілих, наряду з іншими доказами, нерідко покладаються в основу висновку про причини події та винність конкретних осіб. Разом із тим, незважаючи на очевидну інформаційну значимість допиту, слідчі іноді підходять до його проведення без достатньої відповідальності та припускаються помилок, які негативно впливають на подальший хід розслідування. У нашому випадку ситуацію підсилює ще й той факт, що по деяких правопорушеннях фігурують неповнолітні, допит яких оминути неможливо. I хоча певні рекомендації щодо тактики їх допиту розроблені криміналістичною наукою, проте вони практично залишилися поза увагою науковців щодо злочинів, пов'язаних із втягненням неповнолітніх у злочинну діяльність. 